$$
\begin{aligned}
& \text { خروج الكلام عن مقتضى الظاهر في سورة يونس } \\
& \text { د. سعد بن عبدالعزيز الدريهم (*) } \\
& \text { بسم الله الرحمن الرحيم }
\end{aligned}
$$

المقدّمة:

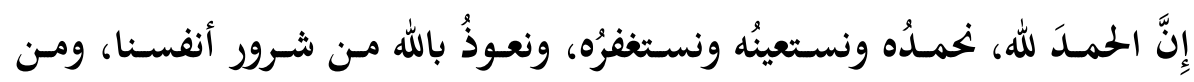

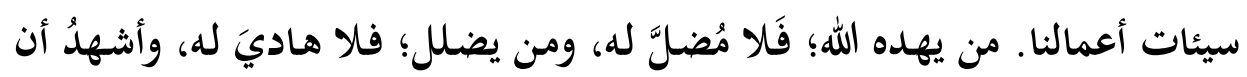
لا إله إلا الله وحده لا شريك له، وأشهدُ أن محمداً عبده ورسوله.

\title{
- (1)
}

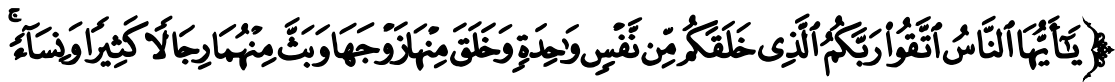

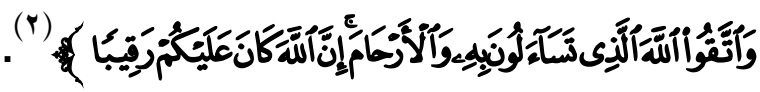

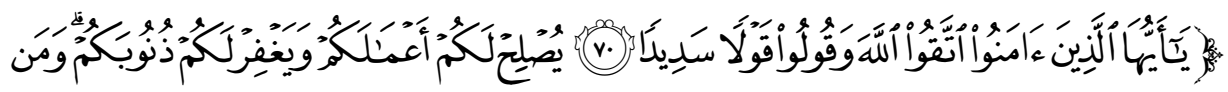

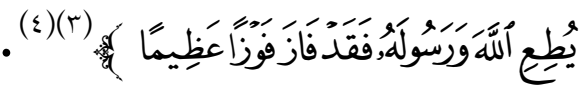

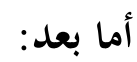

فبِعظم المتكلم يَعظم الكلام، ولا أعظمَ من الله -- سبحانه - وتعالم-؛؛ لذا عظُم كتابه المنزل القرآن الكريم، وعظمت بعظمته وعظمة من تكلم به التَّلي له له والباحث فيه، ولا يزال الإنسان مُعظَّماً ما كان الكتاب العزيز قبلة له: قراءة، وتدبراً، وعملاً به، وتأليفاً فيه؛ لذا كانت وجهتي في أغلب أبحاثي وكُتُبي هذا الكتابُ العزيز؛ أبتغي القرب والثرف العظيم ممن تكلم به- سبحانه -، ولن يزال هذا دأبي ما حييت إن شاء الله؛ خاصة وأن الرفعة لمن كان كذلك جاء منصوصاً عليها في الأثر؛ فقد أخبر النبي - صلى الله عليه وسلم -أن الحخيرية ملازمة لمن تعلَّم القرآن وعلَّمه؛ 
وهل يزهد في مثل هذا الفضل أحد ؟ وهل ثمة من لا يحرك فيه هذا الفضل كوامن

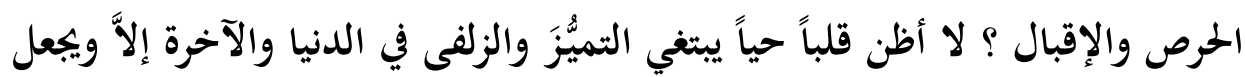

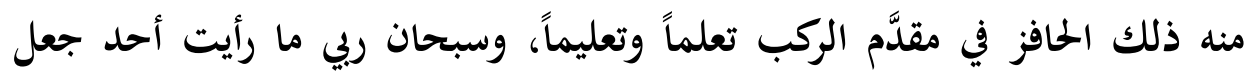

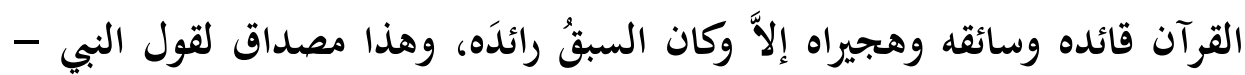

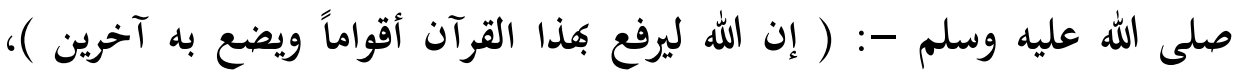
والثفت حولك، وأنعم النظر ستجد أن هناك من سيقت له الشهرة والقبول

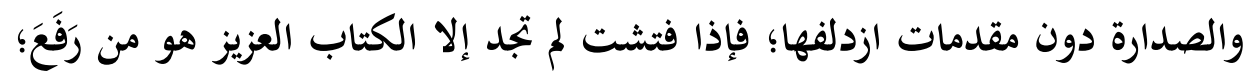
فاللهَ نسألُ أن يجعلنا من أهل القرآن الذين أهله وخاصته. وهنا أقول، ولا أقول ذلك رياء ولا سمعة وإنما تحدثاً بنعمة الله: إنه ومنذ بدأت التهات التهان

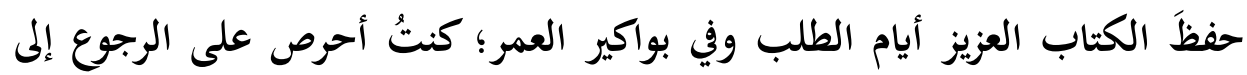

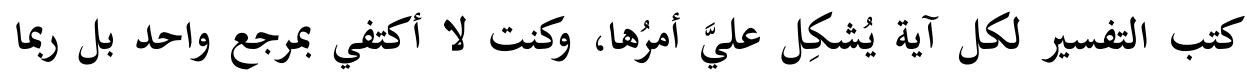

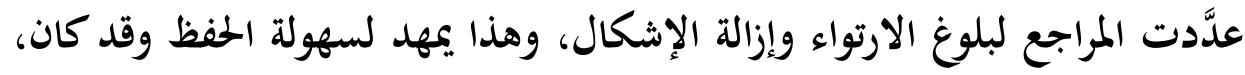

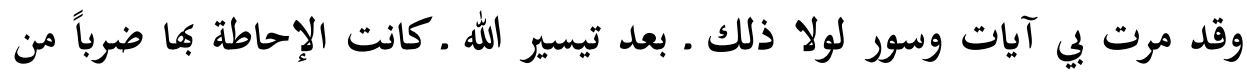
الصعوبة، ومن ذلك (سورة يونس)؛ حيث عانيت بداية منها، ولعل مردَّ ذلك أفها

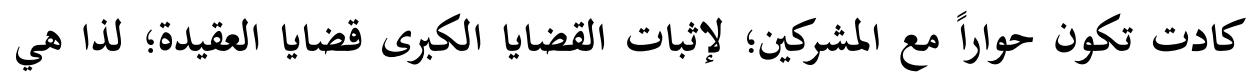

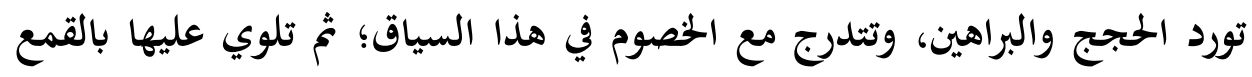

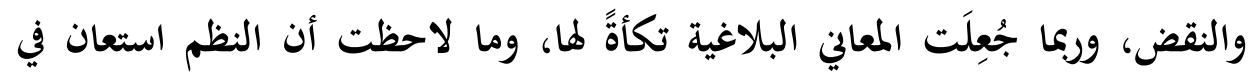
هذه السورة بشيء كاستعانته بخروج الكلام عن مقتضى الظعاهر بأنواعه المختلفة:

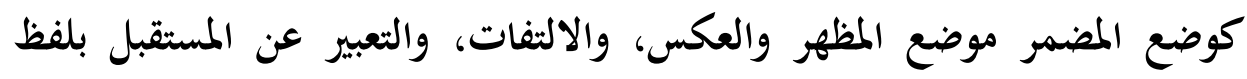

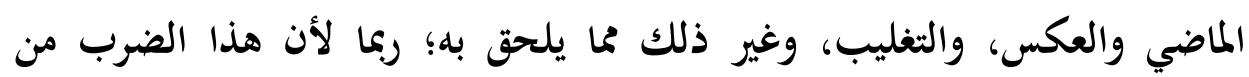

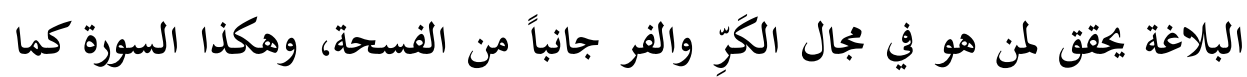

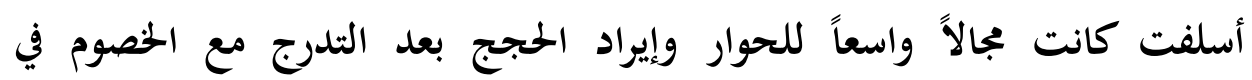

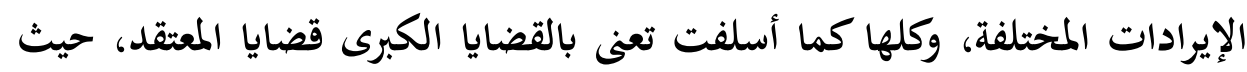


النجاة والهلاك والفوز والحسارة؛ لذا ستكون وقفاتي هنا في هذه البحث حول ( خروج الكلام عن مقتضى الظاهر في سورة يونس )، وهي كانت تعليقات رأيتُ هئ

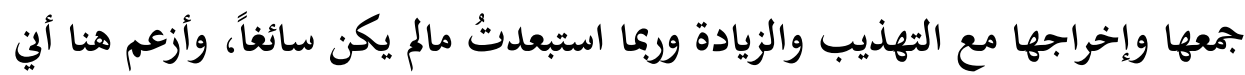
قد استقصيت ما جاء في هذه السورة من قضايا هذه المسألة، وهي ( خروج الكلام عن مقتضى الظاهر )، وسيكون تدرجي مع هذه القضية في هذا البحث مراعى فيه تسلسل الآيات في المصحف ما استطعت؛ لذا تتداخل هنا المعاني. وقد جعلت هذه البحث في مقدمة، وتمهيد اشتمل على أمرين: التعريف بالسورة سورة يونس، وكذلك التعريف بخروج الكلام عن مقتضى الظاهر بأفرعه

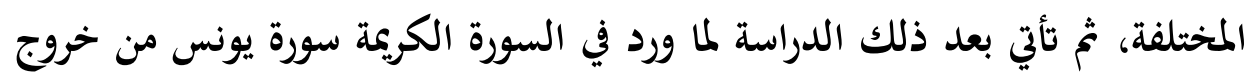
للككلام عن مقتضى الظاهر؛ معالجة وبياناً لأوجه الإعجاز فيه.

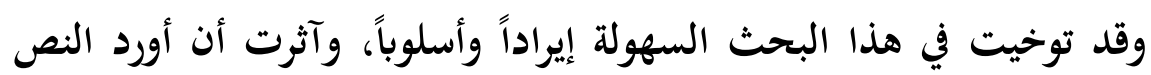
القرآني بخط المصحف العثماني، وكذلك تخريجها وتخريج الأحاديث النبوية وما أوردته إنها

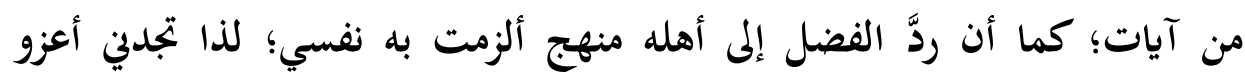

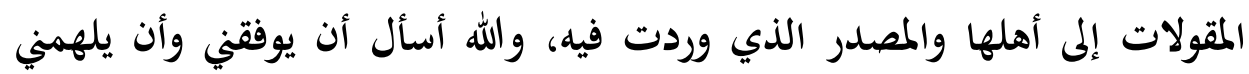

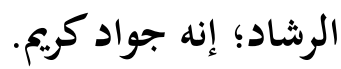

د. - م. سعد بن عبدالعزيز الدريهم الرياض 
التَّمْهْيْدُ

أولاً: الحدِيثُ عَنْ سُورَة يُونُس:

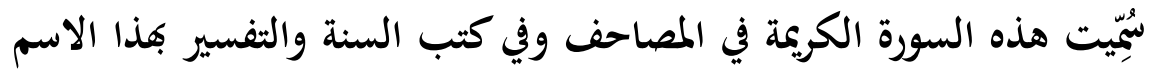

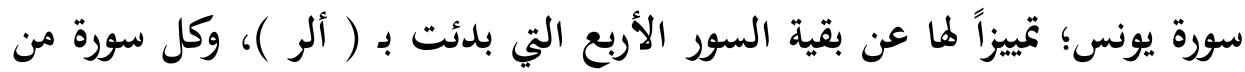

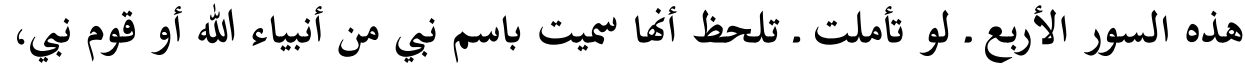

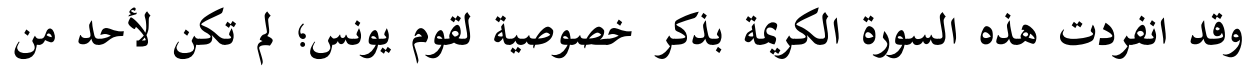

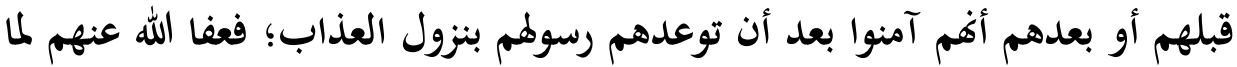

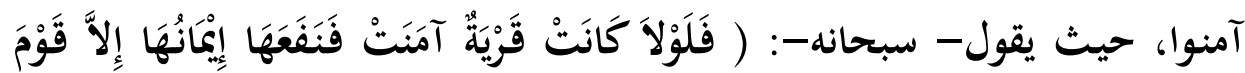

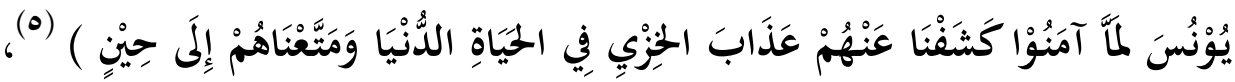
وتلك الحصوصية كرامة ليونس، ولعلك تلحظ أنه لم يذكر يونس؛ في هذه السورة إلا فئا

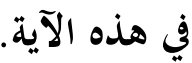

وهذه السورة من السور المكية، وعدد آياتما مئة وتسع آيات، وهي السورة الحادية والحمسون في ترتيب نزول السور؛ حيث نزلت بعد سورة الإسراء في السنة السنة الحادية عشرة من البعثة النبوية. وهذه السورة الكريمة ابتدأت بمقصد إثبات رسالة النبي - صلى الله عليه

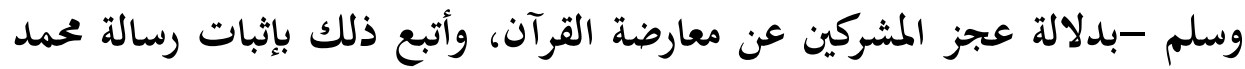

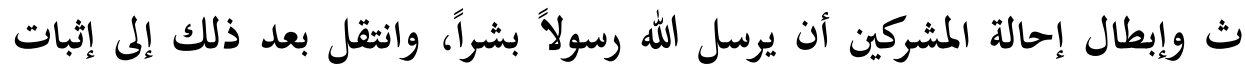
انفراد الله - تعلى - بالإلهية بدلالة أنه خحالق العالم ومدبره؛ فأفضى ذلك إلك إلى إلى إبطال

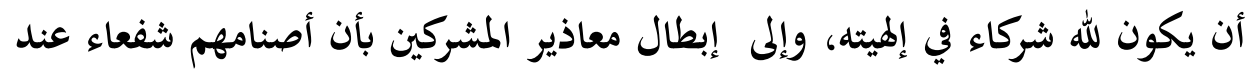
الله، وأتبع ذلك بإثبات الحشر والجزاء؛ فذلك إبطال لأصول الشئاء الشرك.

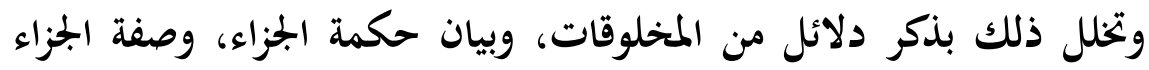

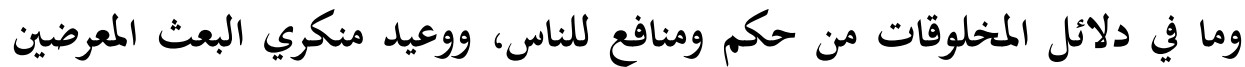

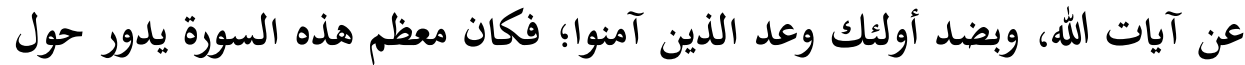

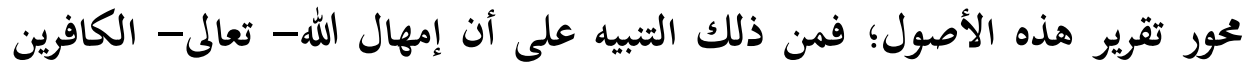

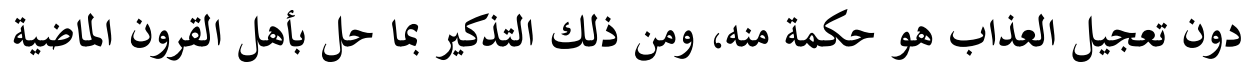


لما أشركوا وكذبوا الرسل، والاعتبار بما خلق الله للناس من مواهب القدرة على السير في البر والبحر، وما في أحوال السير في البحر من الألطاف.

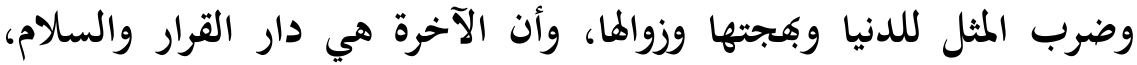

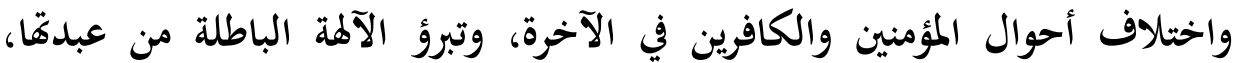
وإبطال إلهية غير الله- تعالى- بدليل أفها لا تغني عن الناس شيئاً في الدنيا ولا في في الداطي

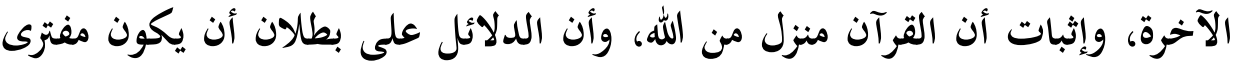
واضحة، وتحدى المشركين بأن يأتوا بسورة مثله، ولكن الضلالة العالة أعمت أبصار

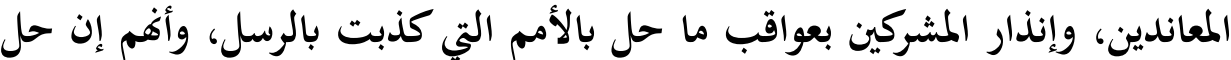

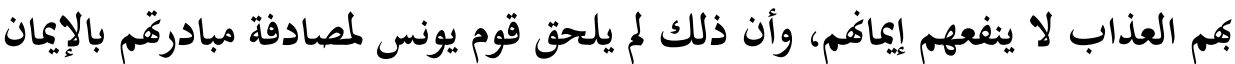
قبل حلول العذاب، وتوبيخ المشركين على ما حرموه مما أحل الله من الرزق، وإثبات

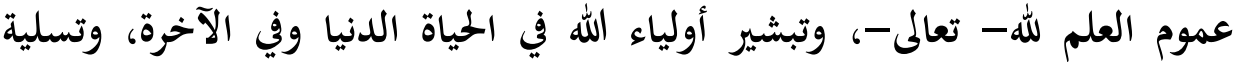

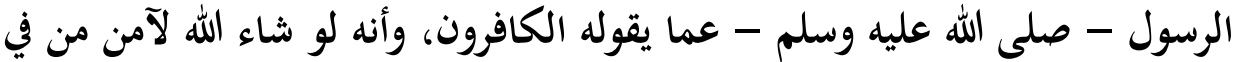

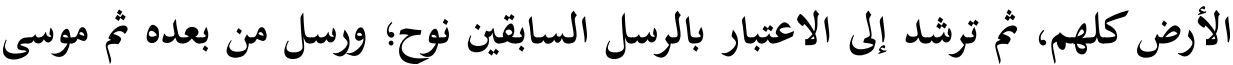

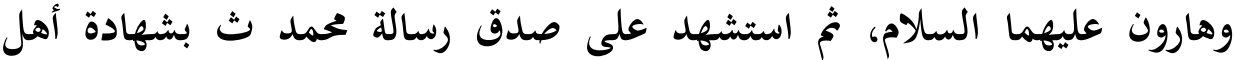

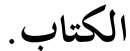

وختمت السورة بتلقين الرسول - صلى الله عليه وسلم - مما يعذر به لأهل الشك في دين الإسلام، وأن اهتداء من اهتدى لنفسه وضلال من ضل عليهال الهوليها، وأن الله سيحكم بينه وبين معانديه.

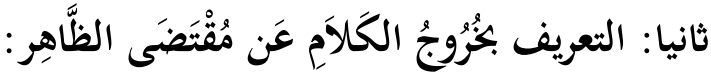
لو عرضنا كل ما قيل في البلاغة العربية؛ لوجدنا أن الفكرة الجوهرية في

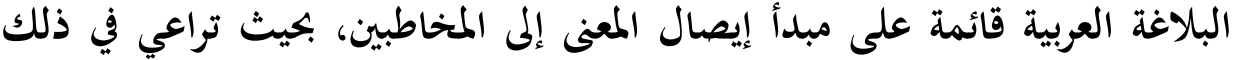
أحوالمم العقلية والنفسية؛ فيجيء الكلام مطابقاً لتلك الأحوال، والبلاغة العربية قد المداند

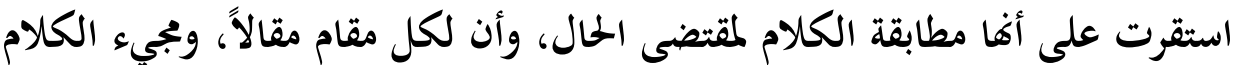
طبقاً لهذا هو أصل البلاغة وشرطها الذي لا بلد منه، ولكن قدابل التأي الكلام مخالفاً لمقتضى الظاهر، وهذا الأمر تقتضيه أسرار ونكات. 


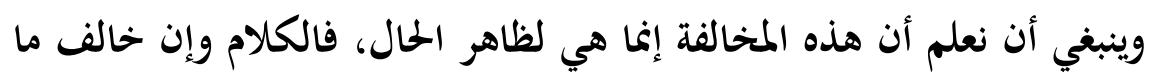
يقتضيه الظاهر؛ فإنه موافق لما يقتضيه المعنى، ويتطلبه المقام، ولا يظهر ذلك إلك إلا لما لمن سبر أغوار المعالي، وتغلغل بفكره في أعماق التراكيب، فهو الذي يتجلى له ما وراء مخالفة الظاهر من أسرار ومزايا وأهداف يقصد إلى تحقيقها (هاج). ولهذا الحروج أساليب وصور مختلفة تحدث عنها البلاغيون. من أهمها: موضع المضمر موضع المظهر، ووضع المظهر موضع المضمر، والالتفات، والتعبير عن

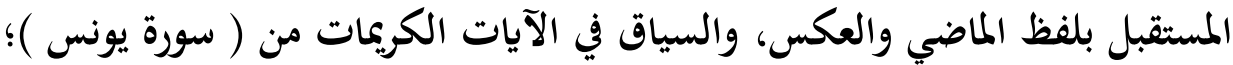
سيجلي لنا الكثير من هذه المعالي، وسيكون الوقوف على كل معنى من المعالني الخارجة عن ظاهرها وتجليته من خلال الآيات الأولى لوروده في هذه السورة المباركة.

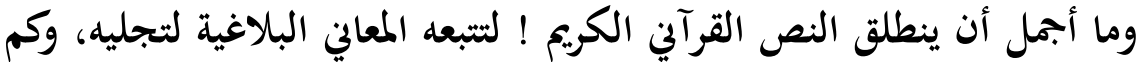
تكون الدراسة ذات عبق عندما تكون على سجيتها لا تركن إلى المبالغة وتحميل النص ما لا يحتمل، أو التقصير الذي يفوت على القارئ جزءاً من المتعة والفائدة، التي انطوى عليها النص وتجاهلها قلم الباحث، والخير كما أسلفت في الوسط بين هذه وتلك.

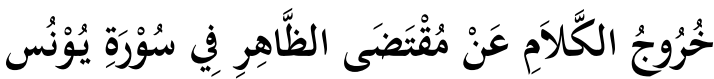

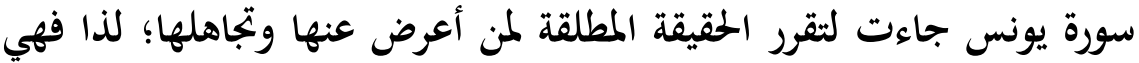
تتفنن في عرض الحطاب، وتعطي كلَّ موقف ما يناسبه من دلالة؛ فتارة يكون مباشراً، وتارة يكون بطريقة أخرى، وكلها لا تجري على نسق واحد في البلاغة؛ لأن البلاغة

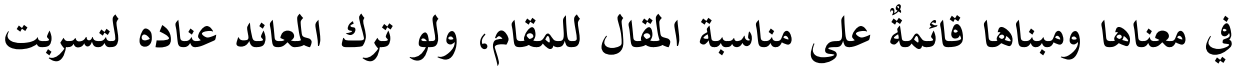
تلك المعالي إلى نفسه تسرب النسيم اللطيف؛ فأخذت بمجامع العقل والقلب منه، وكم أوبقت حظوظ النفس من مكابر حتى أوردته الحفر، ومن يضلل الله فلا هادي

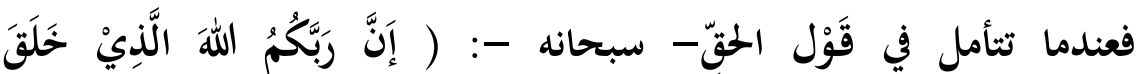

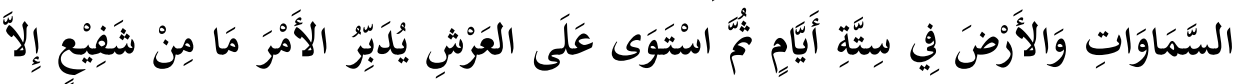

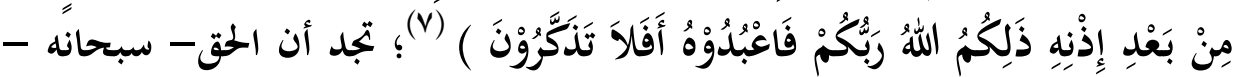


توجه إليهم بالحطاب مباشرة ؛ بينما كان السياق قبل ذلك على سبيل الغيبة كما في

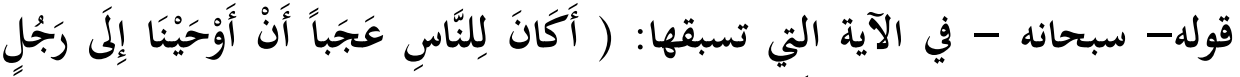

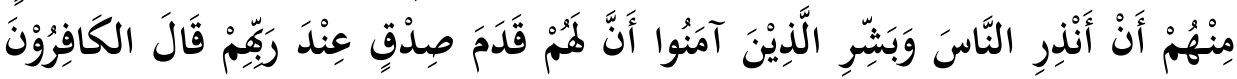

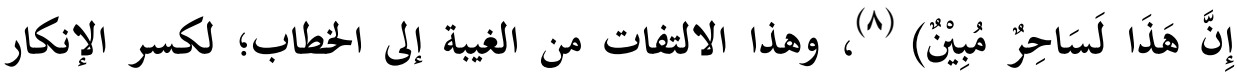

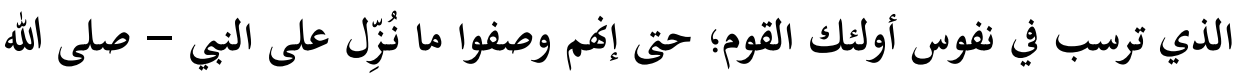

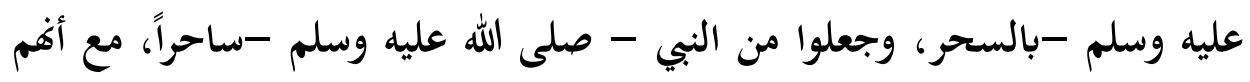

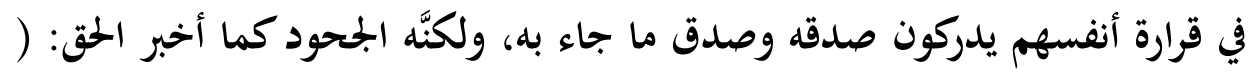

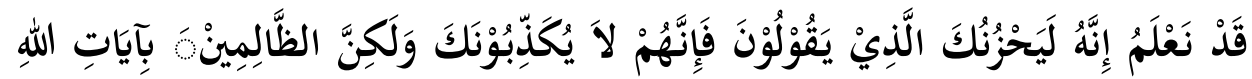

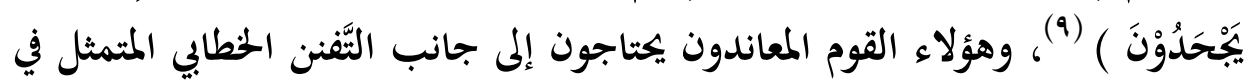

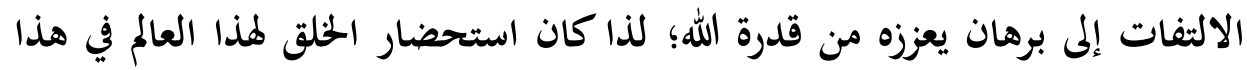

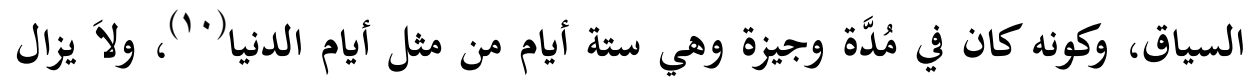

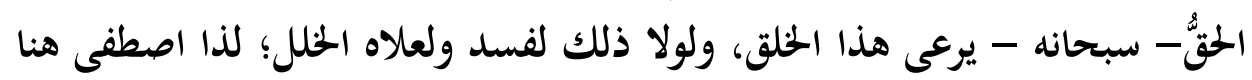

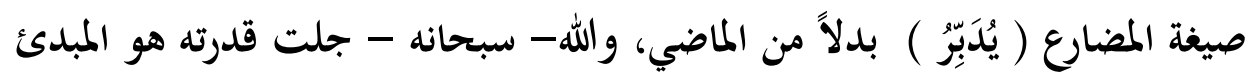

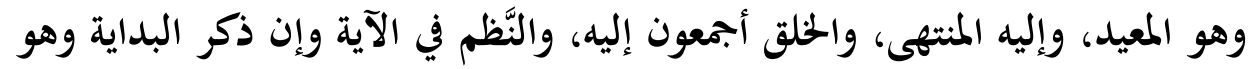

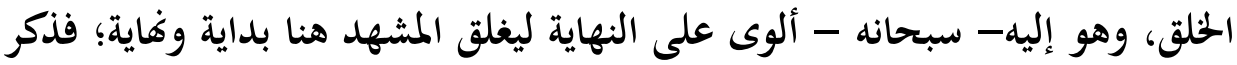

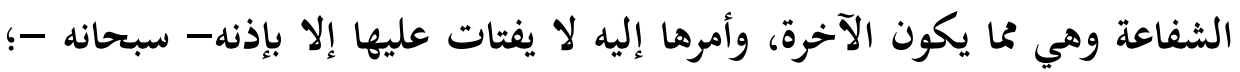

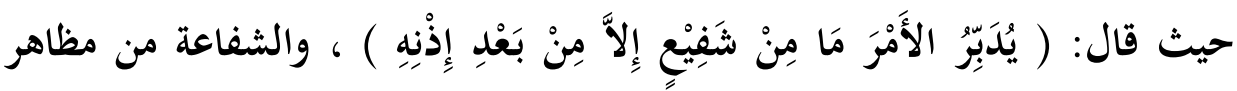
القدرة والتمكن والقهر.

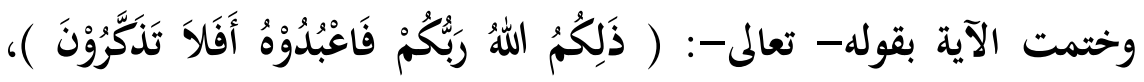

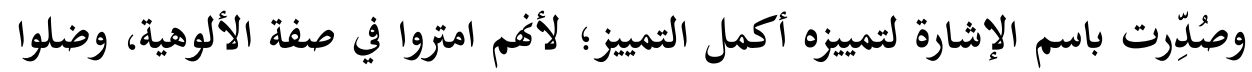

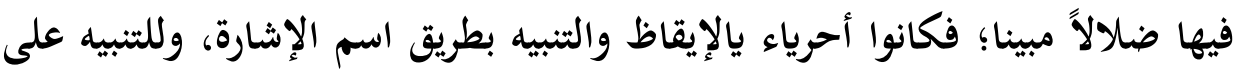

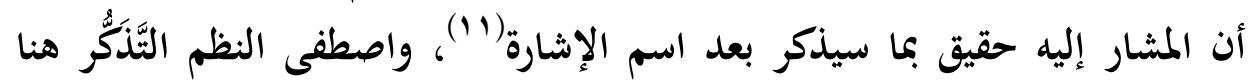

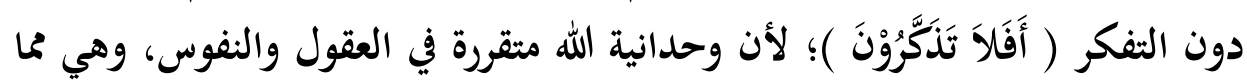

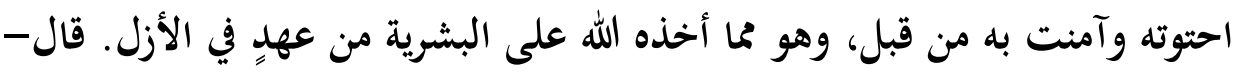

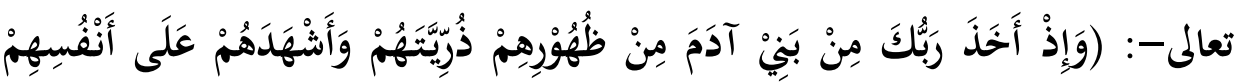




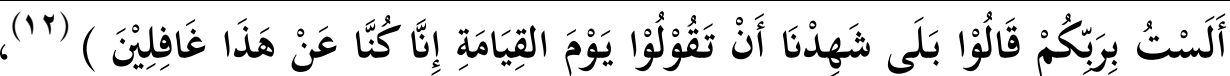

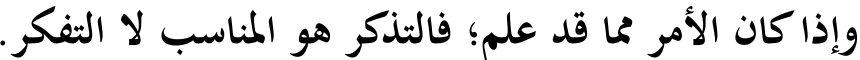

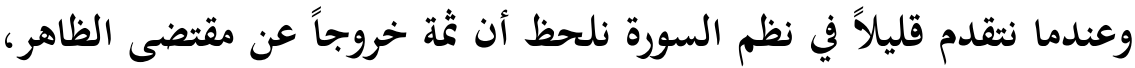

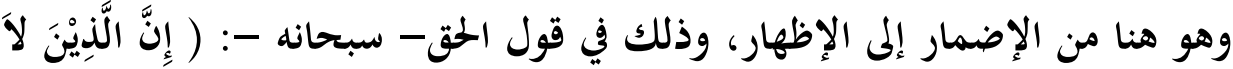

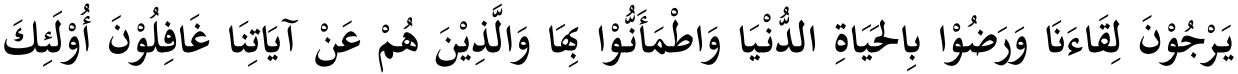

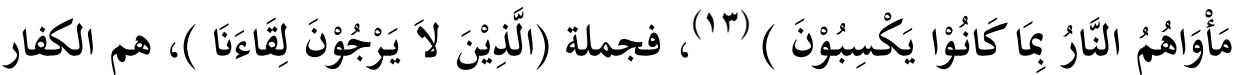

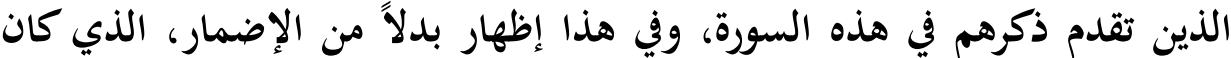

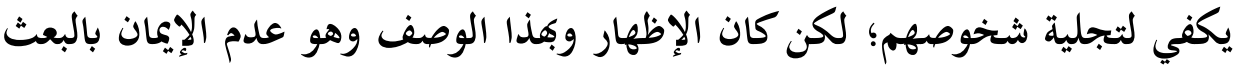

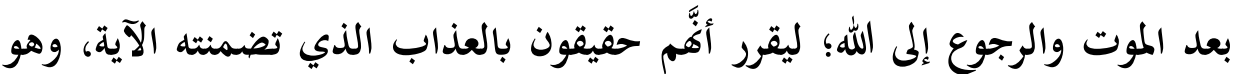

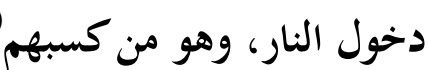

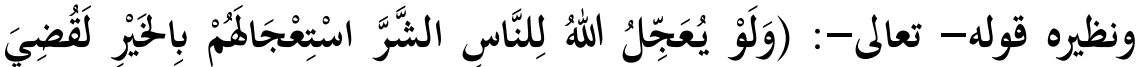

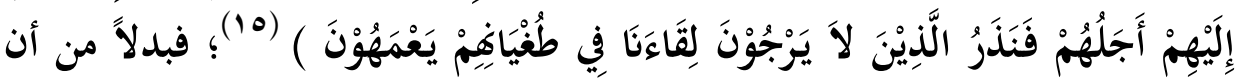
يقول فنذرهم بالضمير عدل عنه إلى الاسم الظاهر وهو الموصول وصلته، فقال:

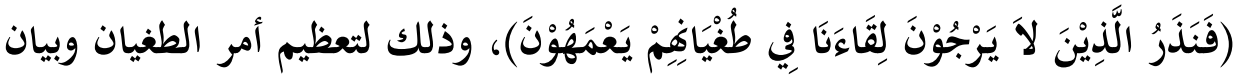

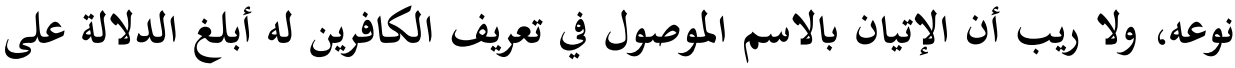

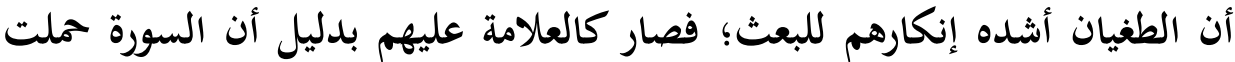

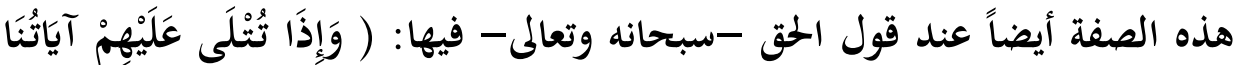

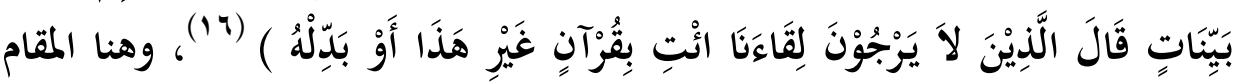

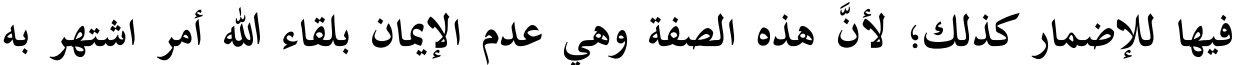

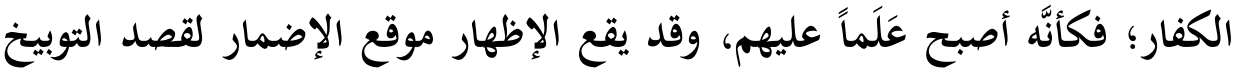

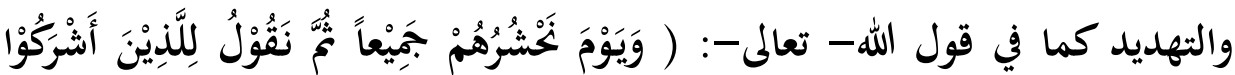

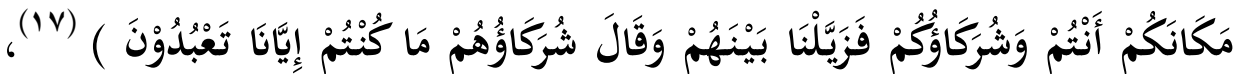

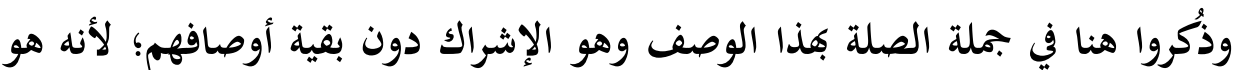
الذي أوبقَهم وأوجب لهم الخلود في النار؛ وإن كان ذلك الكان لا ينفي عنهم بقية الأوصاف وأغم مؤاخذون بها. 


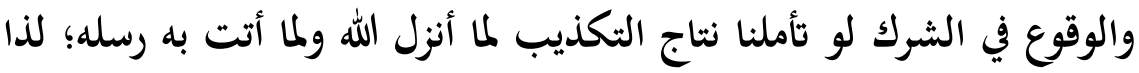

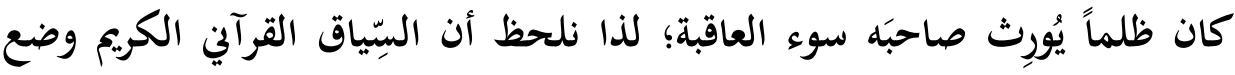

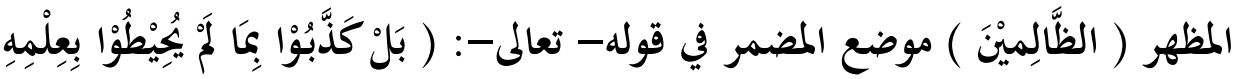

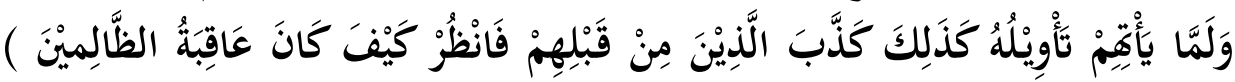

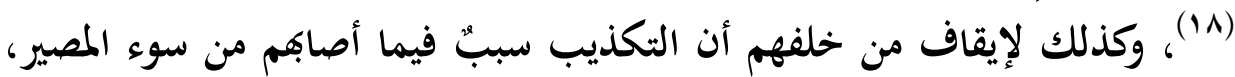
وهو كذلك لاحقق بمن استن بسنتهم

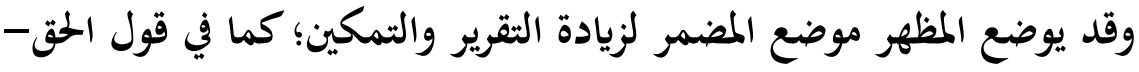

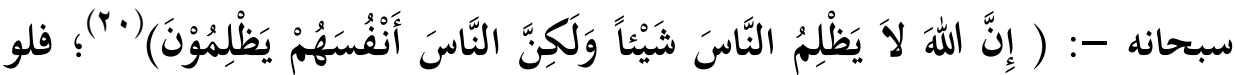

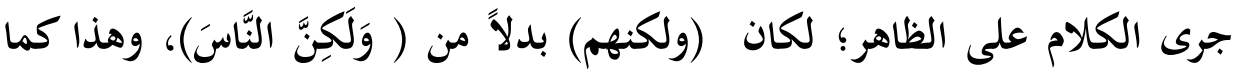

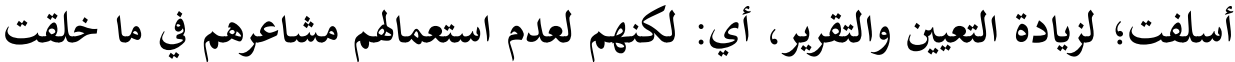

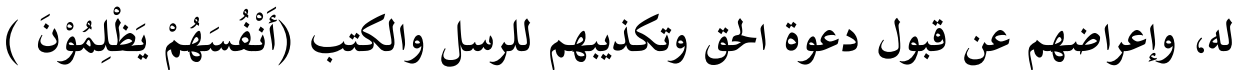

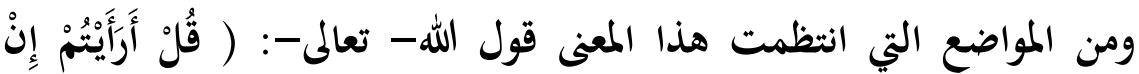

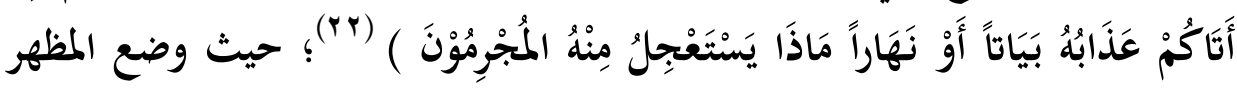

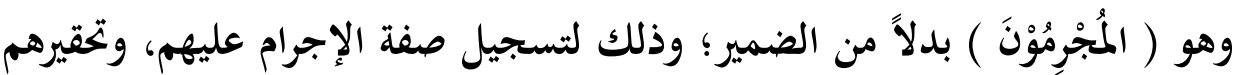

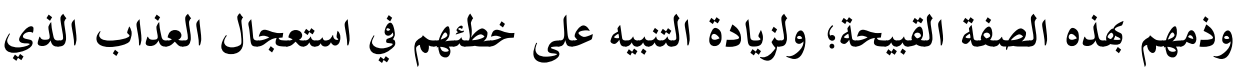

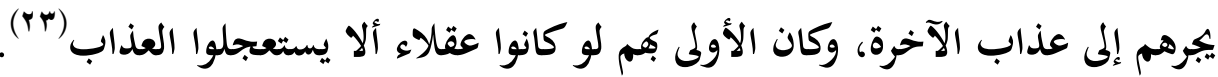

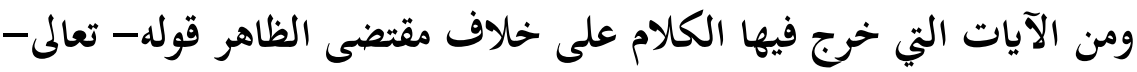

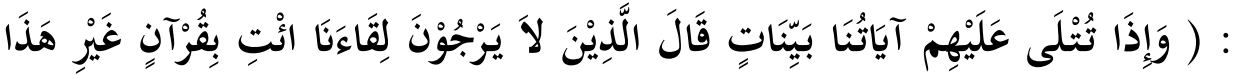

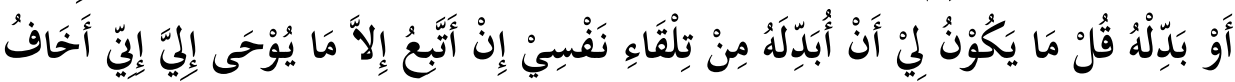

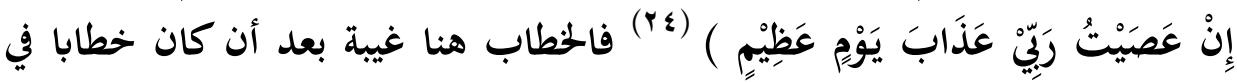

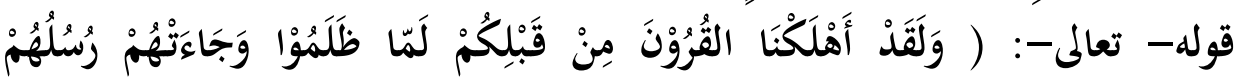

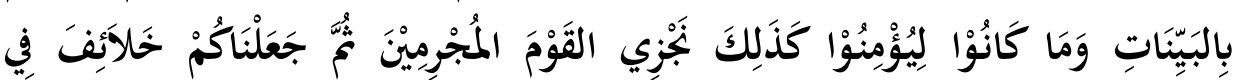

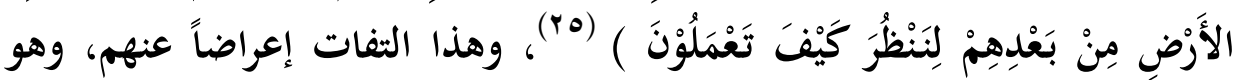
يستحقون ذلك؛ لأفم بتصرفاتم الحمقاء يسيئون لما خلقوا له واستخلفوا من أجله، 
وهو عبادة الله، كما أن إمعاغم في الكفر بالرب والرسول وتكذيبهما يجعلهم جدئيرين

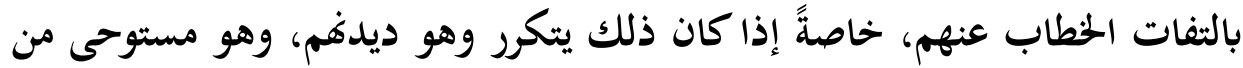

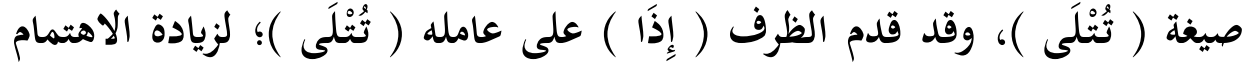

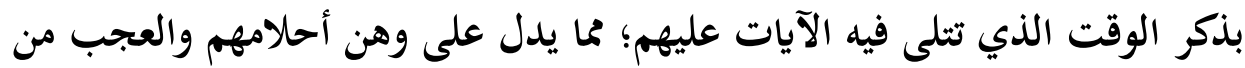

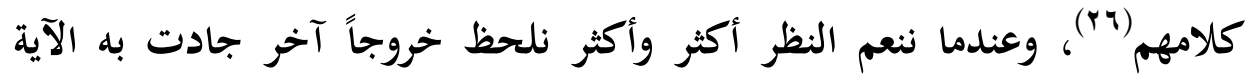

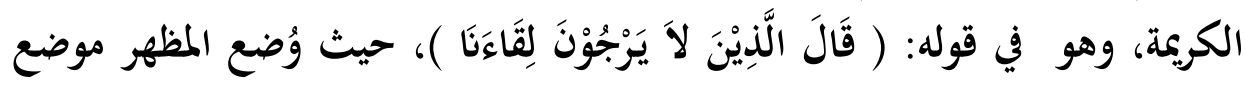

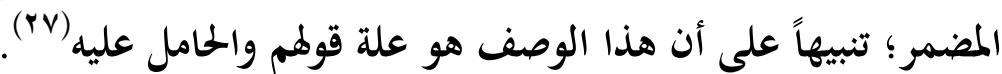

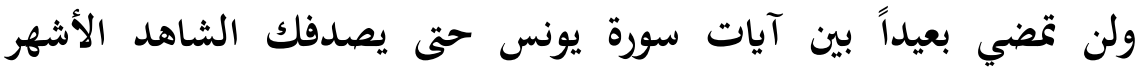

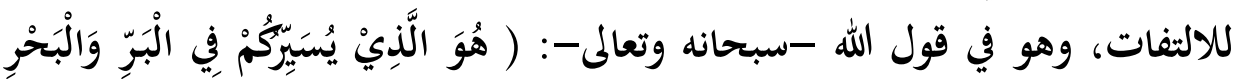

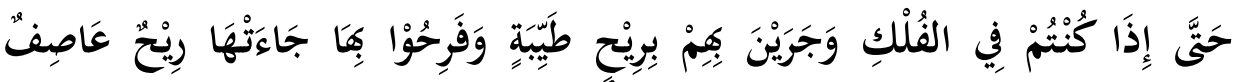

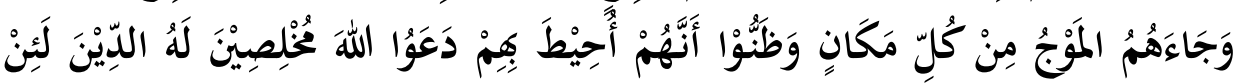

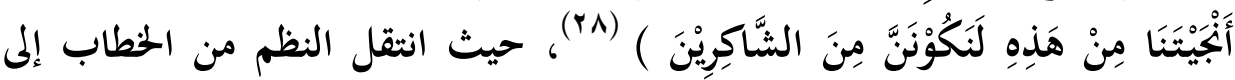

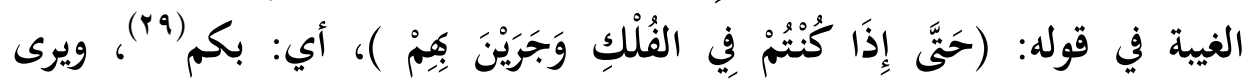

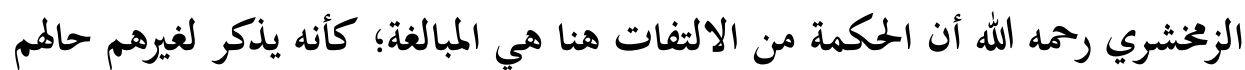

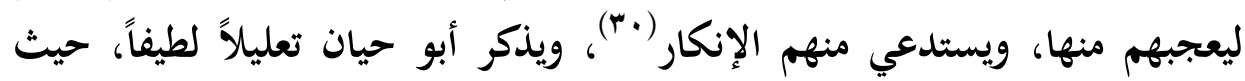

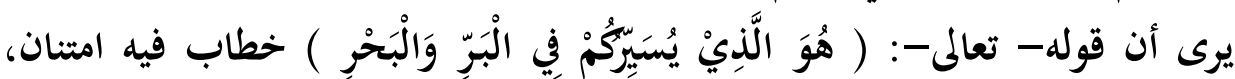

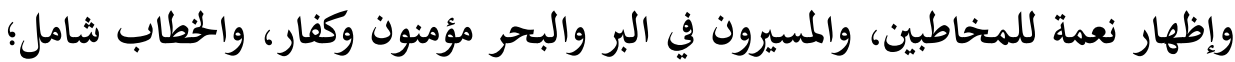

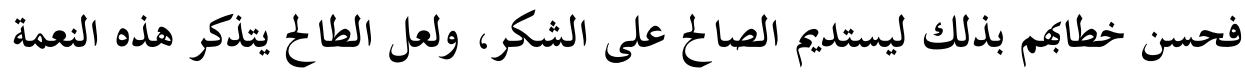

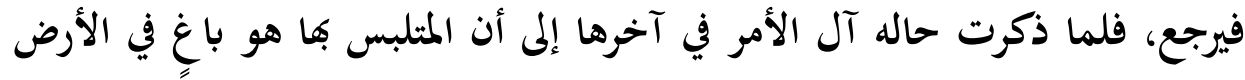

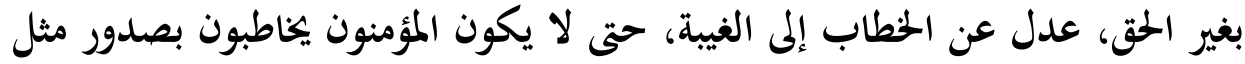

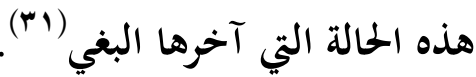

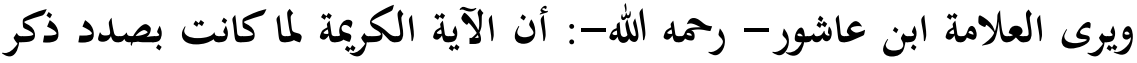

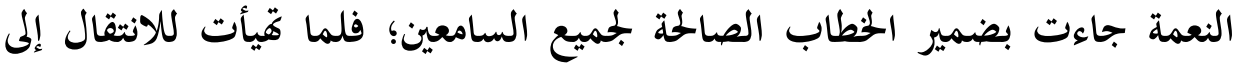

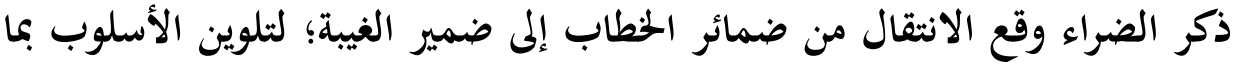

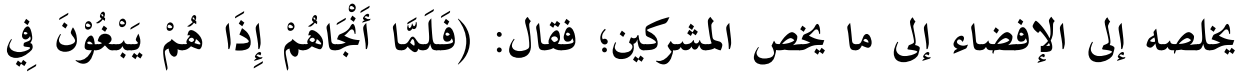




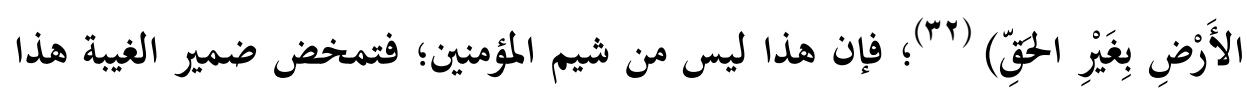

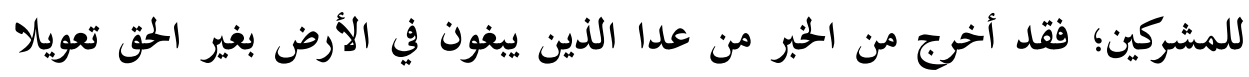
على القرينة؛ لأن الذين يبغون في الأرض بغير الحق لا يشمل المن المسلمين.

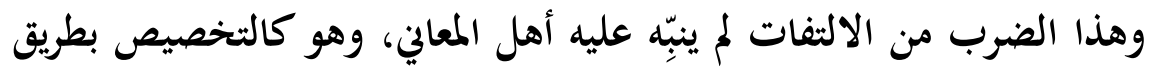
الرمز، وقد عدت هذه الآية من أمثلة الالتفات من الخطاب إلى الغيبة في ضمائر الغيبة كلها تبعاً للكشاف؛ بناء على جعل ضمائر الخطاب للمشركين، وجعل ضمائر الغيبة لمم أيضاً، وما نحوته أنا أليق. وابتدئ الإتيان بضمير الغيبة من آحرَ ذكر النعمة عند قوله: ( وَجَرَيْنَ نِِِمْ

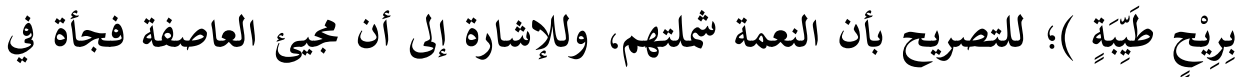

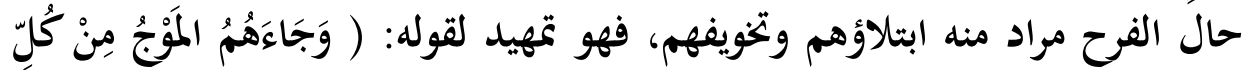
مَكَانٍ (rr)

وهنا لفتة أخرى اشتملها السياق القرآني، وهو التعبير بالإفراد في لفظة (إنها

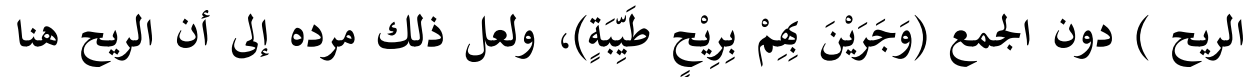
للعذاب، وريح العذاب تأتي من مهب واحد، ولا يقوم لها ما يعارضها، حتى تنتهي إلى حيث أمرت بعكس رياح الرحة فهي مختلفة المهاب والصفات والمنافع، وإذا هاجت

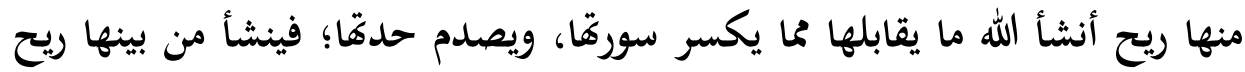
لطيفة تنفع الحيوان والنبات، وعلى هذا النسق جاء نظم القرآن، حيث يقول-

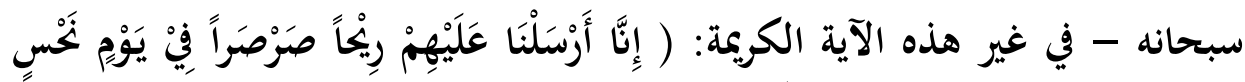

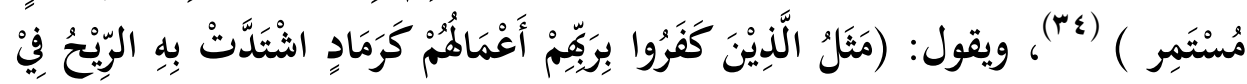

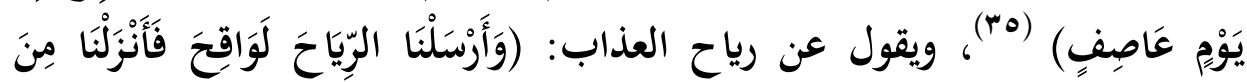

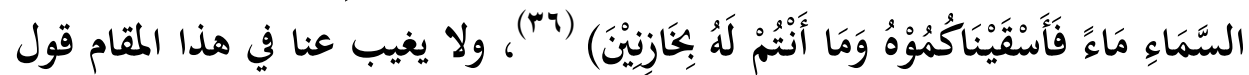
النبي - صلى الله عليه وسلم -إذا هاجت الريح: ( اللهم اجعلها رياحاً ولا تجعلها ريحاً ).

ومن صور الالتفات التي جاء بما النظم القرآي الكريم في سورة يونس الانتقال

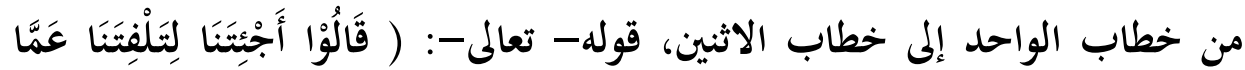




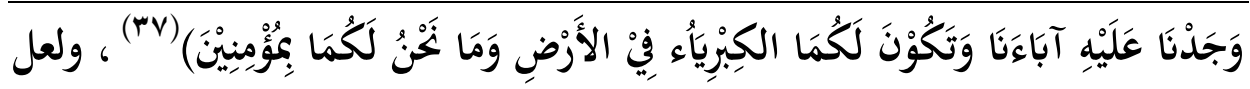
توجيه الخطاب لموسى عليه السلام وحده بداية لقوته على بني إسرائيل؛ ولأنه أول

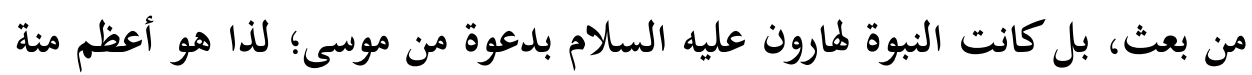
في الدنيا لأخ على أخية هي منة موسى على هارون إذ حُبي النبوة بسببه عليه

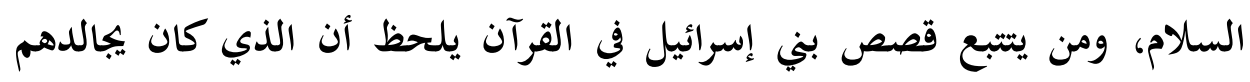

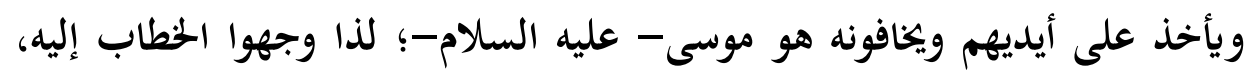
فقد أنكروا عليه هنا في بداية الآية الكريمة دعوته لهم إلى التوحيد، وأنه إنما جاءهم

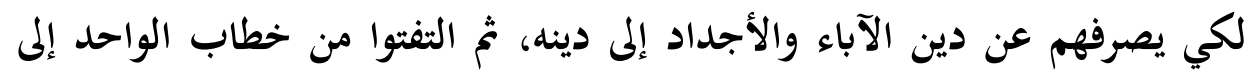

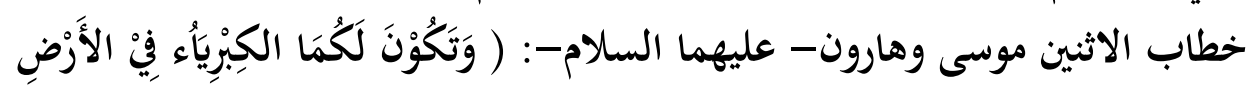

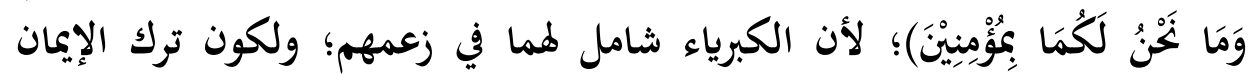

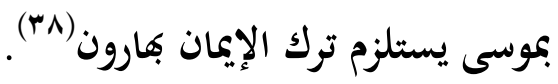

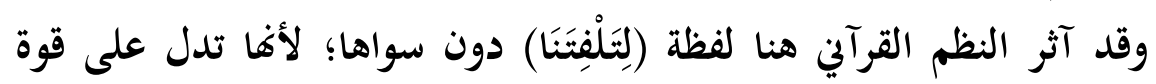
التحول والعدول، كقوة تمسكهم بعبادة الأصنام بدلالة الحرف الذي يؤكد تمكن

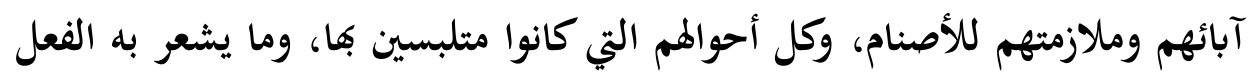

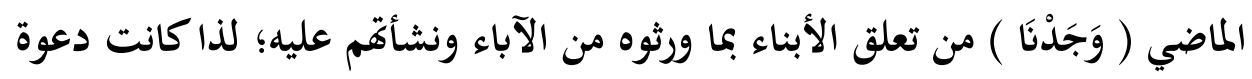

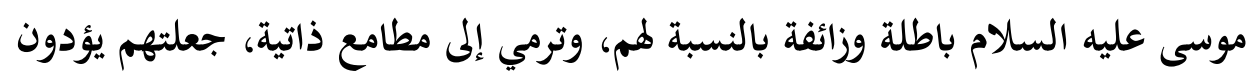

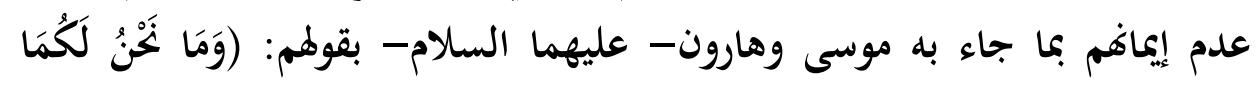

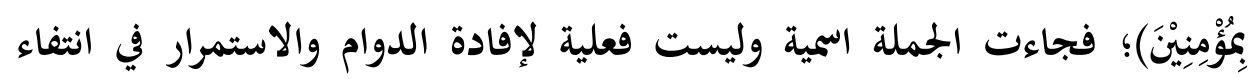

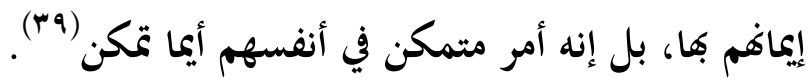

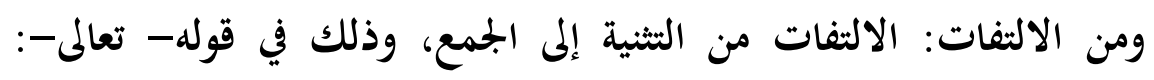

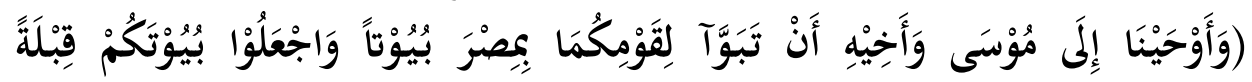

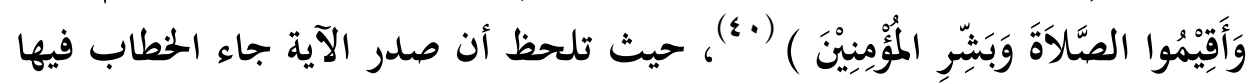

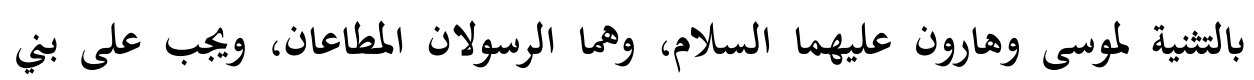

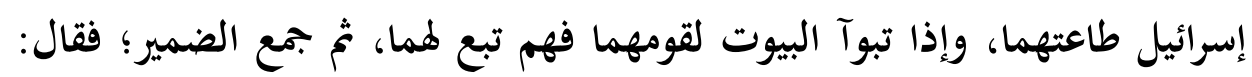

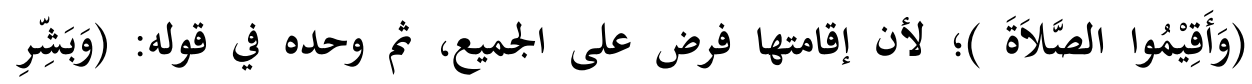


المُؤْمِنيْنَ)؛ لأن موسى؛ هو الأصل في الرسالة، فهو الأصل في البشارة، وأيضاً فإِان

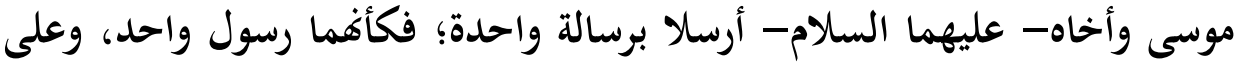

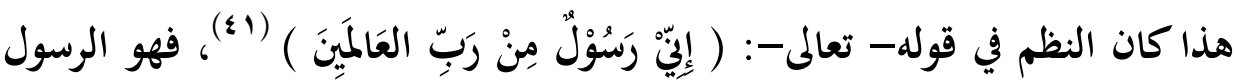
الذي قيل له: ( وَبَثِّرِ المُؤْمِنْينَ ) ).

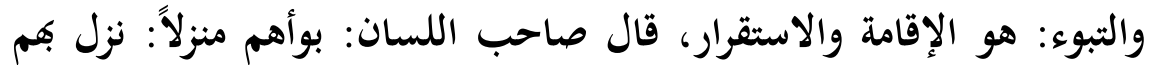

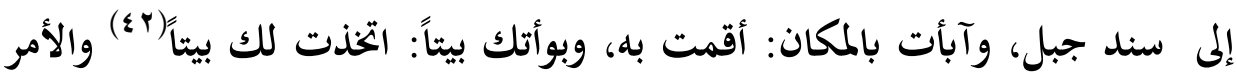
باتخاذ البيوت لعل المراد به: الانتقال من البيوت المؤقتة من خيام ونها إلى البيوت البهات

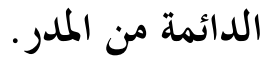

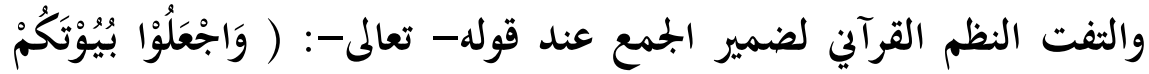

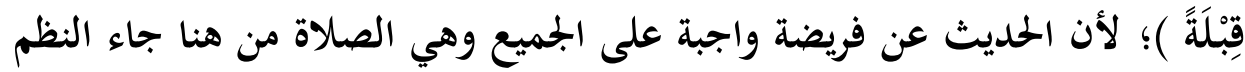

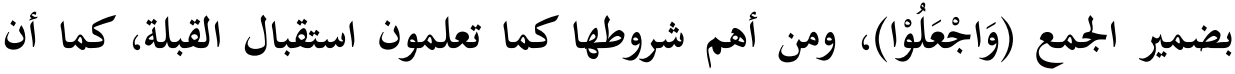

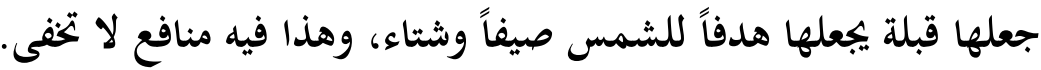
والناس أثناء جلبتهم وحواكهم؛ خاصة وهم مطاردون من قبل العدو فرعون وجنودهم؛ ربما جعلهم ذاهلين وفي غفل عن صلاقتم؛ لذا جاء الذكر بتعيينها والنص

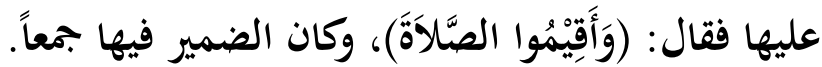

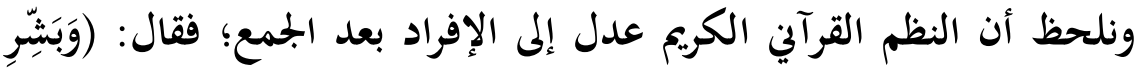

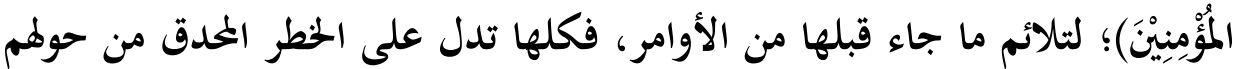

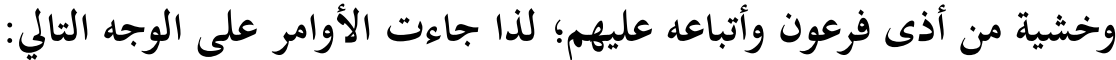
أولاً: باتخاذ مساكن أخرى قابلة للارتحال.

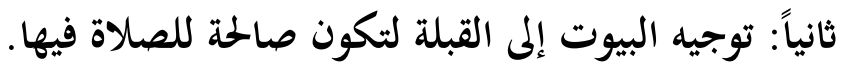

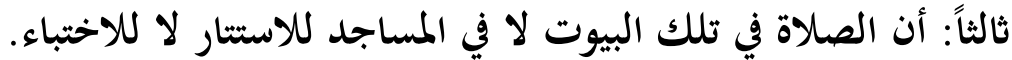

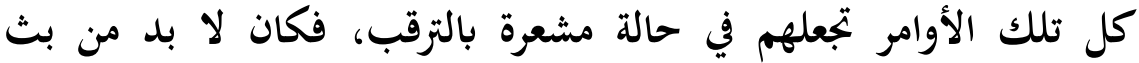

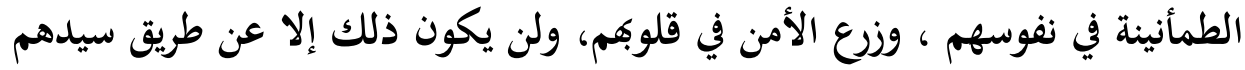
وقائدهم كليم الله على العدو المتربص فرعون.

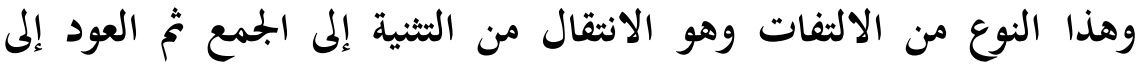




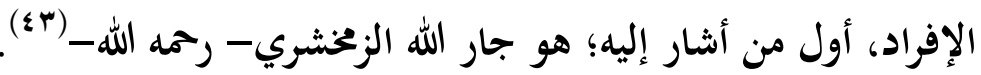

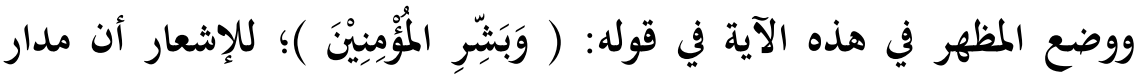

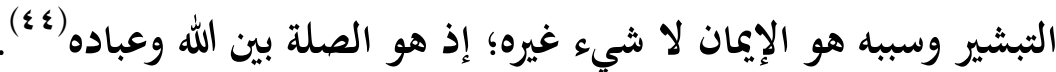
ومن صور خروج الكلام على خلاف مقتضى الظاهر في هذه السورة الكريمة المباركة التغليب، وهو بعبارة البلاغيين إعطاء أحد المتصاحبين أو المتشابهين حكم

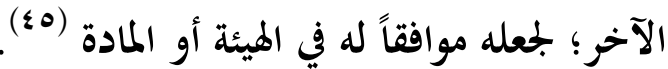

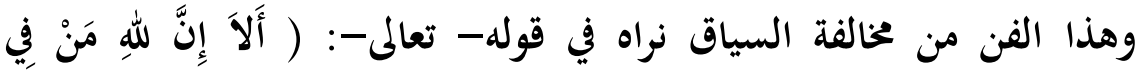

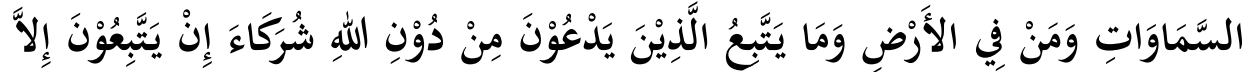

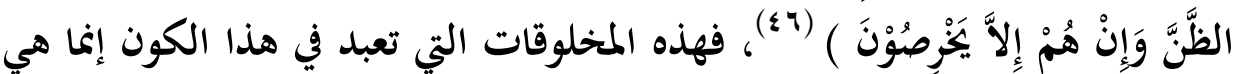
من خلق الله - سبحانه وتعالى-، ولا يستوي من يخلق بمن لا يخلق، وفي النظرة الأولى لمن له عقل ولب أن يرعوي عن عبادة هذه المخلوقات ومساواتحا بمن خلقهاسبحانه -، ولكنها النظرة المعوجة والعقول النخرة التي غاب عنها الاتزان؛ فساوت بين العظيم- سبحانه - والحقير من خلقه في ألزم الأمور وهي العبادة؛ وعندما تغيب العقول ويرى الإنسان بمحض هذه العقول المختطفة زيناً ليس بالزين، فلا ريب أنه قلبه أشرب الفتنة وانغمس فيها قلبه؛ حتى صارت مسلمة؛ لذا نرى الله - سبحانه وتعالى - يخاطبهم في هذه الآية منطلقاً من هذا الأساس؛ ججاراة للخصم في فئ المناظرة

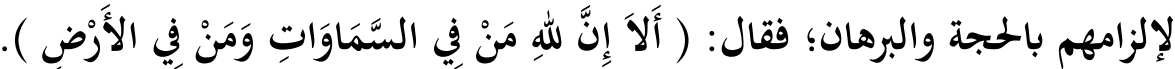

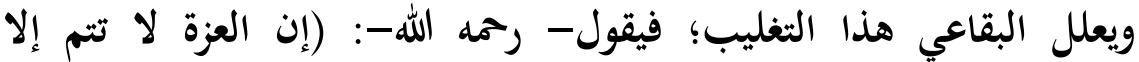
بالقدرة؛ فأثبت اختصاصه بالملك الذي لا يكون إلا بها؛ فقال مؤكداً لما يستلزمه

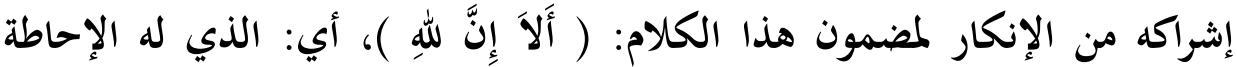
الكاملة، ولما كان بعض الناس قد أشركوا ببعض النجوم؛ جمع فقال معبراً بأداة إلها

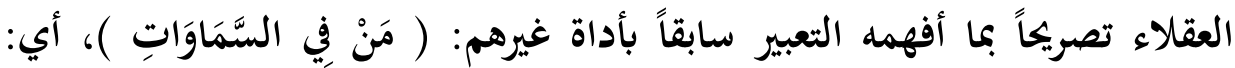

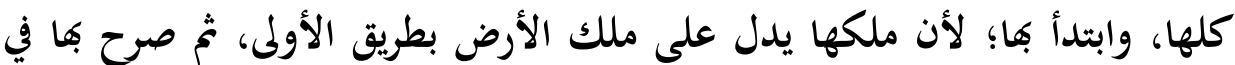

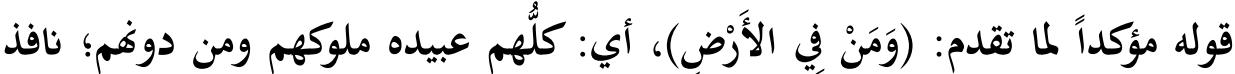

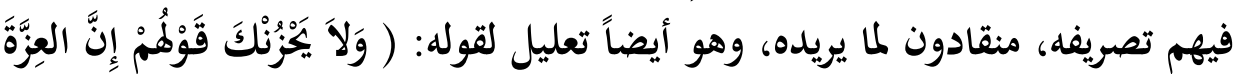




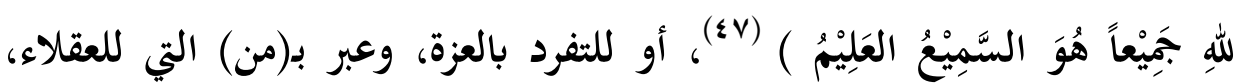

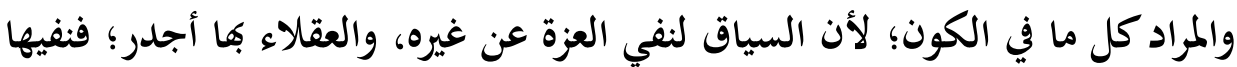

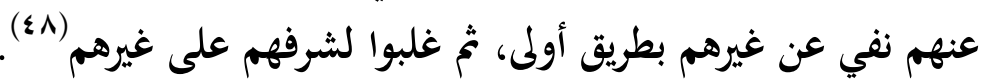

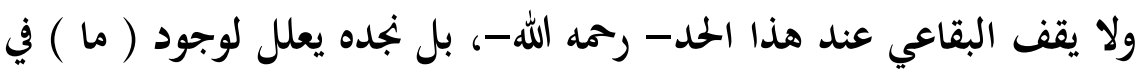
آية تسبقها، وأخرى تليها؛ فيقول: ( ولذا تطلق ( ما ) التي هي لغيرهم في سياق هو

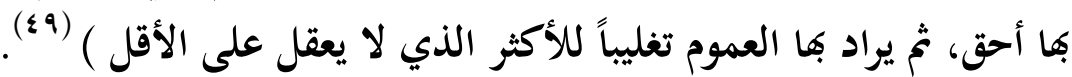
وهو يشير بذلك لقوله- تعالى - في سورة يونس: ( ألاًا إِنَّ للهِ مَاِفي السَّمَاوَاتِ

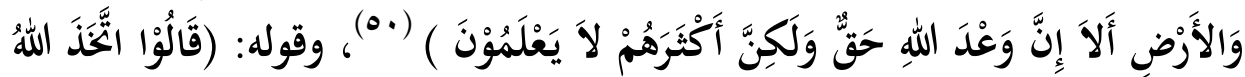

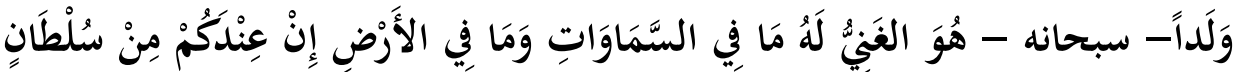

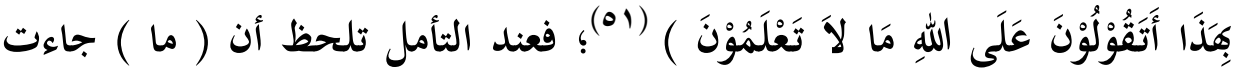
لتدل على غير العقلاء والعقلاء عن طريق التغليب بالأكثر؛ وهو لصالح غير العقلاء؛ فالآية الأولى قد وردت في قضية إثبات البعث والجزاء، التي ينكرها الكفار والمشركون؛ إلا أغا دليل على قدرة الحي القيوم- سبحانه - وتصرفه المطلق في

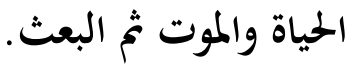

يقول البقاعي رحمه الله: ( ثم بين غناه بقوله: ( مَا فِي السَّمَاوَاتِ )، ولما كان

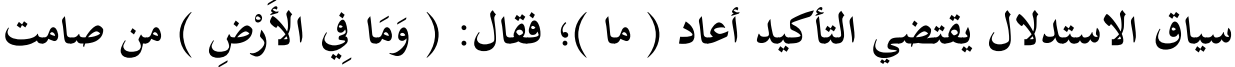
وناطق، فهو غني بملك ذلك عن أن يكون شيء منه ولداً له؛ لأن الولد لا يملك،

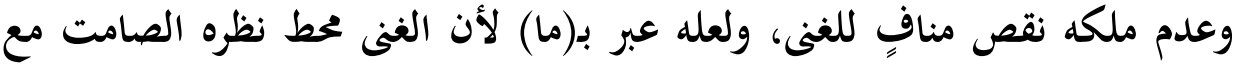

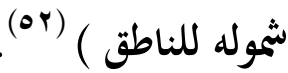

وبمذه اللطيفة أختم هذا البحث، والله أسأل أن يجعلني مباركاً وأن ينفعني، وينفع بي إنه جواد كريم. الخايتة والنتائج

مهما أفاض الإنسان في دراسة الآي الحكيم من الكتاب العزيز؛ لن يزداد إلا

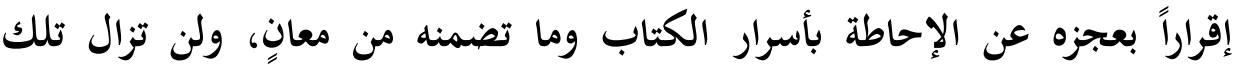
القراءات وتلك الدراسات التي يمتع نفسه باستنباط تلك الدرر وتلك الطرائف منها 
تسلمه إلى عجز، وهو يلتقط ويغترف تلك الدرر وتلك الفرائد كأنه في خضم بحر متلاطم لا ساحل له في مركب رث صغير، وهذا دأبنا ومن قبلنا مع الكتاب العزيز وآيته، كل يأتي ليؤدي مهمته ليمتح ما كتب له من لطائف وطرائف الكتاب العزيز؛ ليأتي من بعده ليكمل المهمة، وما زال هذا القرآن مكتنزاً بما يدهش.

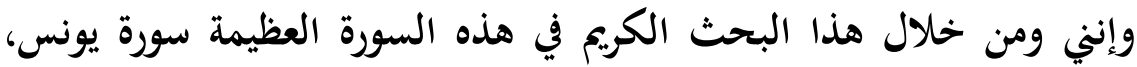
والتي تخيَّت فيها الوقوف على خروج الكلام عن مقتضى الظاهر، وكم كان هذا

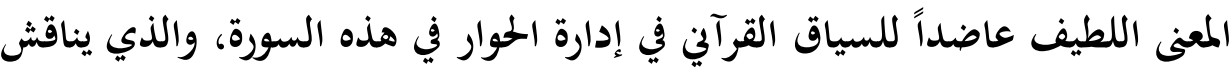
التوجهات العقدية التي اختطها بعض البشر بعيداً عن رحبة العقيدة القرآنية الصافية؛ فاجتالتهم الشياطين؛ فكانوا في حزب الشيطان، وبئس والله سبيلاً. عندما تنعم النظر وتتأمل تلحظ أن السياق القرآي نوع توجهاته في مخاتلة ذوي التوجهات الإلحادية المنحرفة، وتلك التي انتقص جناب التوحيد في نفوسهم؛ فتارة يستخدم الالتفات، وتارة باستخدام المظهر مكان المضمر والمضمر مكان المظهر والتغليب؛ لذا تترادف هذه المعاني وتنثال بين آي هذه السورة التي أخلصت

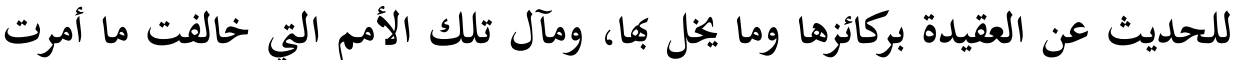
بله، وعصت رسل ربما؛ حتى أورثها الحبال، لتلحق يوم القيامة بدار الأشرار، وكم بائس ظن أنه على شيء فإذا هو وقود النار؛ إنك وأنت تقرأ وتصافح الآيات بقلبك تتأوه من عظمة ما مر بك من عظمة الإعجاز والإيجاز وشدة الإفحام، وفي الدراسة لمن قرأها وعانقت عيناه بعض حروفها تجلية لشيء من ذلك، والله أسأل أن يجعل

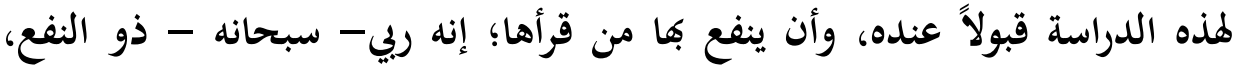

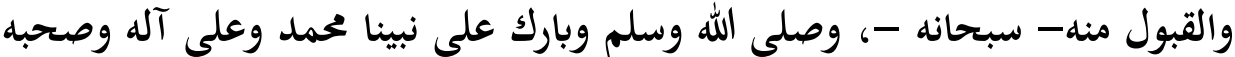
أجمعين.

\section{فهرس المراجع}

ا. . إرشـاد العقـل السـليم إلى مـزايا القـرآن الكـريم، أبـو السـعود محمـد بـن محمـد العمادي، دار إحياء التراث العربي، بيروت.

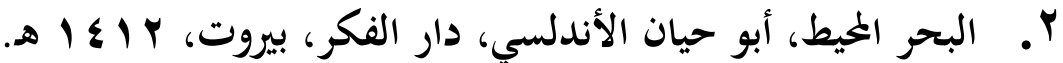


r ب. بغية الإيضاح لتلخيص المفتاح، عبدالمثعال الصعيدي، مكتبة الآداب، مصر.

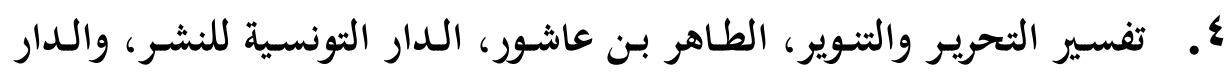
الجماهيرية للنشر والتوزيع. •.خطبة الحاجة، محمد بن ناصر الدين الألباني، المكتب الإسلامي، بيروت، ط لط I MqV r 7 . سنن أبي داود، تحقيق: عادل محمد، وعماد عباس، نشر: مركز البحوث بدار

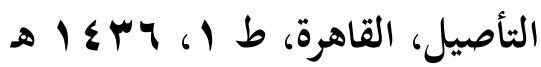

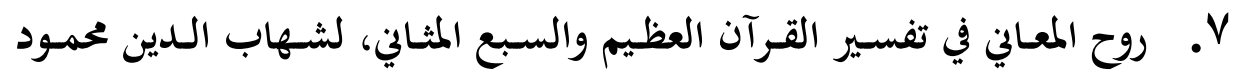

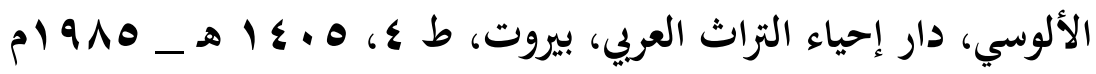

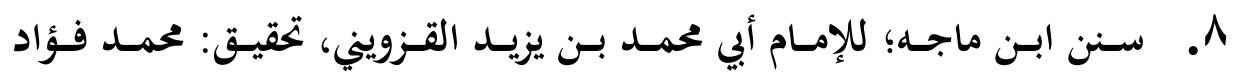

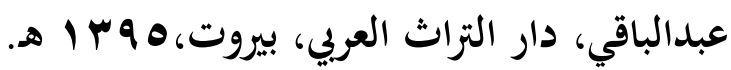
9. فتح القدير الجامع بين فني الرواية والدراية من علم التفسير، الإمام الشوكالي، دار المعرفة، بيروت.

• 1 ـ الكشـاف عـن حقـائق غـوامض التنزيـل وعيـون الأقاويـل في وجـوه التنزيـل، الزخشري، دار الكتاب.

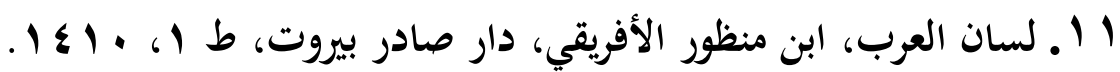


ب جلة الدراسات الإسلامية والبحوث الأكاديمة

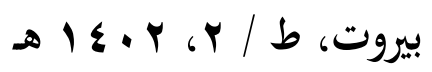

rا 1 ـ مســد الإمـام أحمـد بـن حنبل، شـرح وتحقيق: أحمـد شـاكر، أتمـه د. الحسـيني،

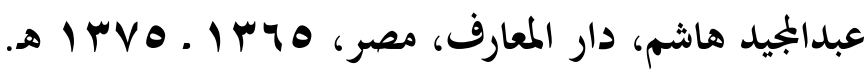

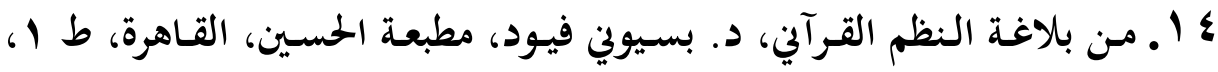

$$
\text { ه } 1 \text { \& }
$$

ه 1 نظم الدرر في تناسب الآيات والسور، الإمام البقاعي، دار الكتاب الإسلامي،

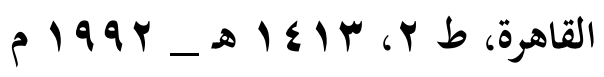




$$
\begin{aligned}
& \text { (1) (1) آل عمران: ب • 1. } \\
& \text { (Y) (Y) النساء: } 1 . \\
& \text { (ك) الأحزاب: • V) }
\end{aligned}
$$

( ) هذه خطبة الحاجة التي كان رسول الله انظر: خطبة الحاجة للشيخ محمد ناصر الدين الألباني، طبع المكتب الإسلامي.

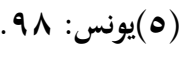

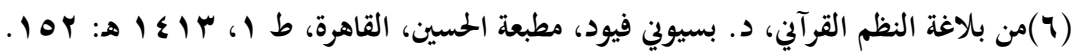

$$
\text { (l) }
$$

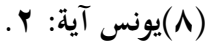

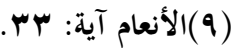

( • (1)روح المعالي في تفسير القرآن العظيم والسبع المثاني، لشهاب الدين الدين محمود الألوسي، دار إحياء التراث

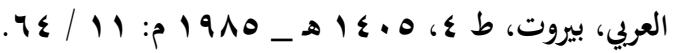

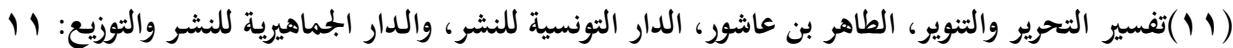

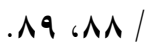

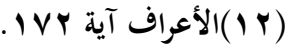

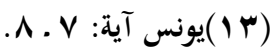

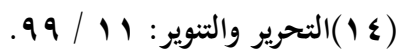

$$
\begin{aligned}
& \text { (10)(1) (1) } \\
& \text { (1) (1) يونس آية: } 10
\end{aligned}
$$

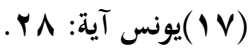

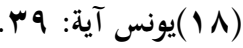

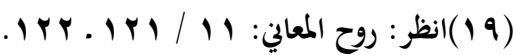

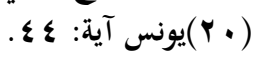

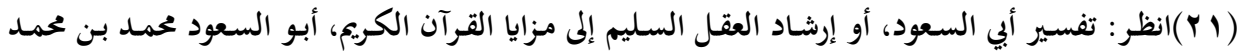

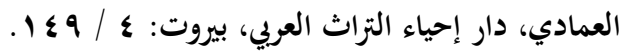

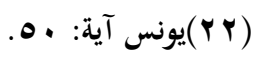

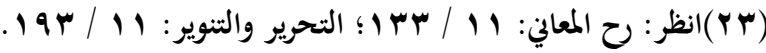

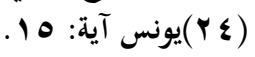

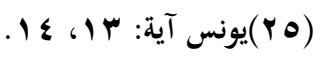

إ)

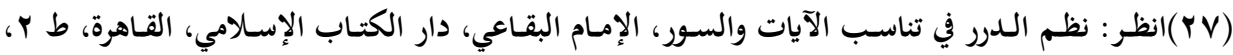

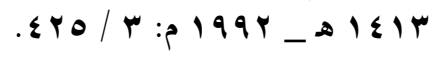

$$
\text { (rی) }
$$

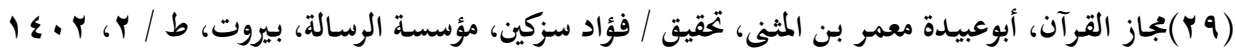




\section{$11 / 1: 0$}

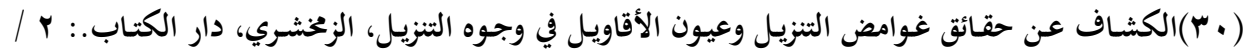

ו

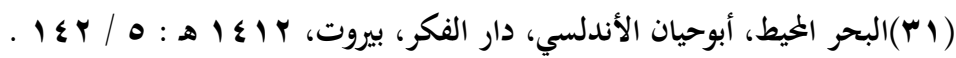

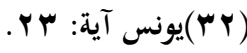

( )

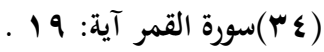

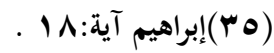

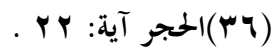

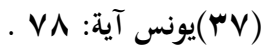

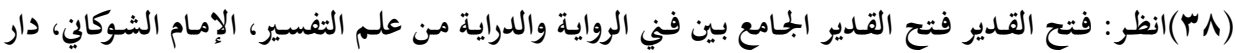

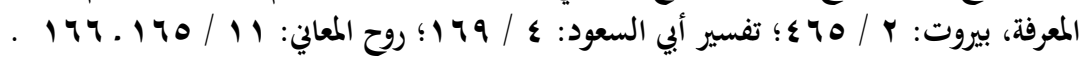

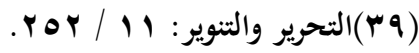

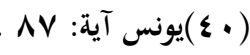

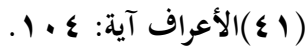

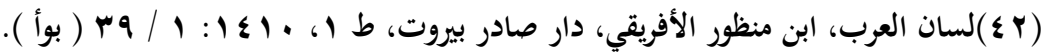

(

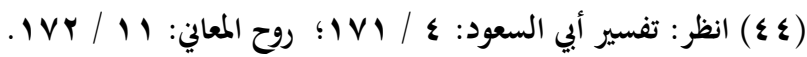

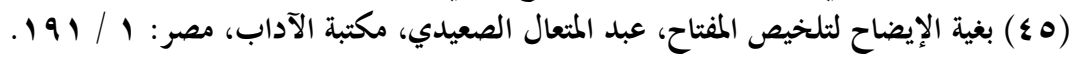

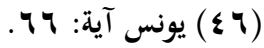

(\&V)

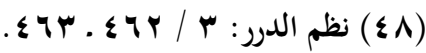

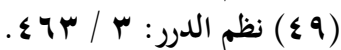

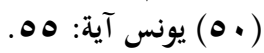

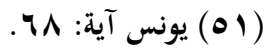

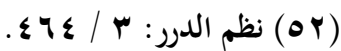

